\title{
Precocious Puberty
}

National Cancer Institute

\section{Source}

National Cancer Institute. Precocious Puberty. NCI Thesaurus. Code C79704.

Unusually early sexual maturity. 